\title{
RESULTS OF TREATMENT OF PATIENTS WITH MIDFACIAL FRACTURES
}

\author{
Khudyk Anton, Grigorov Sergey \\ Kharkiv National Medical University \\ https://doi.org/10.35339/ic.8.2.115-122
}

\begin{abstract}
Background. Fractures of the bones of the facial skeleton, in particular the midface area, are one of the most frequent reasons for patients to apply to maxillofacial inpatient care, not only in Ukraine but also abroad. Along with more modern treatment technologies (osteosynthesis using titanium miniplates and minigrid for fixation bone fragments), methods of repositioning of fragments with subsequent tamponade of the maxillary sinus with iodoform tampon and without tamponade and fixation of fragments are used. A certain group of patients is treated conservatively, which is associated with their reluctance to undergo surgery, minimal displacement of fragments or minimal cosmetic and functional impairments. The purpose of the study. Comparative evaluation of the results of treatment of patients with fractures of the midface area by repositioning the fragments of the zygomatic-orbital complex without fixating the fragments and their subsequent fixation by tamponade of the maxillary sinus with iodoform tampon. Object and methods of research. The comparison was made of the results of treatment of 70 patients with fractures of the midface area, among which 13 patients were treated by the method of repositioning fragments of the zygomaticorbital complex (ZOC) without fixation and without maxillary sinus tamponade, 29 patients underwent repositioning of ZOC fragments with subsequent fixation of fragments with iodoform tampon - the tamponade of the maxillary sinus was performed on the affected side. For comparison, the results of conservative treatment of 28 patients with fractures of the midface area were used. Results. It was found that the reliable $\left(\chi^{2}=11.43 ; \mathrm{p}<0.05\right)$ majority of patients $(64 \%)$ sought treatment within $0-3$ days after injury. $83-89 \%$ of patients who underwent repositioning of the fragments had fresh small-fragment fractures. The reliable $\left(\chi^{2}=11.43 ; \mathrm{p}<0.05\right)$ majority of them simultaneously had 3-4 sites of bone fractures of the midfacearea, hemosinus of varying degrees and paresthesia in the infraorbital area. In the majority of patients who underwent repositioning of bone fragments with and without tamponade ( $85 \%$ and $93 \%$, respectively), the final displacements ranged from 3.1 to $6 \mathrm{~mm}$. In patients treated conservatively, in most cases $(93 \%)$ the displacements were greater than $3.1 \mathrm{~mm}$, which remained after treatment. Conclusion. In the majority of patients treated with the studied methods, in the long term, the displacement of bone fragments remained, which had functional and cosmetic consequences. In all studied groups, a certain cosmetic effect was achieved over time, as evidenced by a reliable $\left(\chi^{2}=160.9 ; p=0.00000\right)$ decrease in the indicator by the VAS.

Keywords: fractures of the midface area, reposition of fragments without fixation, reposition of fragments with fixation, tamponade of the maxillary sinus, computed tomography, visual analogue scale.
\end{abstract}

\section{Introduction}

Traumatic fractures of the maxillofacial area account for 14 to $17 \%$ of all facial injuries [1]. The frequency of severe or complex maxillofacial

Corresponding Author:

Anton Khudyk, MD, PhD student

of the Department of Surgical Dentistry

and Maxillofacial Surgery, Kharkiv National

Medical University, Kharkiv, Ukraine.

E-mail: vodoo999@gmail.com injuries, according to a number of authors, has been declining over the past 10 years [2].

Traumatic fractures of the bones of the facial skeleton, in particular the midface area, are one of the most frequent reasons for patients to apply to maxillofacial inpatient care, not only in Ukraine but also in foreign countries [3-9].

It is known that fractures of the midface area cause severe deformities, which affects the appearance of patients' faces [10]. 
Quite often these fractures cause various other concomitant pathological conditions that can cause impaired nasal breathing, occlusion, vision, etc. [11].

The most common injuries of the skull and maxillofacial area occur as a result of road traffic accidents, street and household injuries, injuries in the area of military conflicts $[12,13]$.

In order to achieve the maximum cosmetic and functional result in patients with midface fractures, treatment should be started as soon as possible [14].

Surgical methods of treatment are most often used in Ukraine and in near and not-so-near abroad for the treatment of midface fractures with displacement of fragments [15-17]: reposition of fragments without fixation and reposition of fragments with fixation, which is performed by tamponade of the maxillary sinus with iodoform of 28 patients with fractures of the mid face area (third group), who were treated conservatively or refused surgery were used for comparison.

All patients in the first group were male. The average age of patients was $(29.6 \pm 10.8)$ years old with a range of 20 to 57 years, i.e. all patients were of working age. The second group consisted of $28(97 \pm 3.2) \%$ of men and one woman. The mean age of patients was $(29.4 \pm 9.6)$ years old with a range of 18 to 62 years. Of all patients in this group, only one patient was of retirement age. The group of patients receiving conservative treatment of fractures of the midface area consisted of 28 people, among whom there were 25 $(89 \pm 5.9) \%$ of men and $3(11 \pm 5.9) \%$ of women. Of all patients in this group, only one patient was of retirement age.

Table 1 shows the distribution of patients in the study groups by the mechanism of injury.

Table 1

Distribution of patients with fractures of the midface area by the mechanism of injury, (\%)

\begin{tabular}{|c|c|c|c|c|}
\hline \multirow[b]{2}{*}{ Mechanism of injury } & \multicolumn{3}{|c|}{ Group } & \multirow[b]{2}{*}{$\begin{array}{c}\text { Total } \\
(n=70)\end{array}$} \\
\hline & $\begin{array}{c}1 \\
(n=13)\end{array}$ & $\begin{array}{c}2 \\
(n=29)\end{array}$ & $\begin{array}{c}3 \\
(n=28)\end{array}$ & \\
\hline Falling & $4(31 \pm 12.8)$ & $14(48 \pm 9.3)$ & $10(36 \pm 9.1)$ & $28(40 \pm 5.9)$ \\
\hline Household & 0 & 0 & $3(10 \pm 5.7)$ & $3(4.0 \pm 2.3)$ \\
\hline Criminal & $8(62 \pm 13.5)$ & $15(52 \pm 9.3)$ & $11(37.7 \pm 5.7)$ & $34(49 \pm 6.0)$ \\
\hline Due to road traffic accident & $1(7.0 \pm 5.9)$ & 0 & $3(10 \pm 5.7)$ & $4(6.0 \pm 2.3)$ \\
\hline Industrial & 0 & 0 & $1(3.6 \pm 2.8)$ & $1(1.0 \pm 0.9)$ \\
\hline
\end{tabular}

tampon, external fixation, using a Kirschner wire, balloon tamponade of the maxillary sinus, Foley catheter, etc. [18-23].

Thus, it is of practical interest to compare common methods of treating midface fractures of different etiology and localization in order to further improve them.

\section{Purposes, subjects and methods:}

2.1. Purpose of the study was the comparative evaluation of the results of treatment of patients with fractures of the midface area by repositioning the fragments of the zygomaticorbital complex without tamponade of the maxillary sinus and repositioning the fragments of the zygomatic-orbital complex with subsequent tamponade of the maxillary sinus.

\subsection{Subjects \& Methods}

We compared the results of treatment of 70 patients with fractures of the midface area, among whom 13 patients were treated by the method of repositioning the maxillary sinus fragments without fixation and without maxillary sinus tamponade (first group), 29 - by the method of repositioning fragments with maxillary sinus tamponade (second group). The results of treatment
According to the data of Table 1 it can be noted that the largest number of injuries was criminal (49\%) and as a result of falling (40\%), other types of injuries were rare.

The examination of patients at hospitalization included: general clinical blood and urine tests, biochemical blood tests, electrocardiography, $\mathrm{X}$-ray or fluorography of thoracic organs, conebeam computed tomography (CBCT) of the skull/ midface area.

Evaluation of the severity of clinical manifestations of traumatic injuries before treatment, as well as the course and outcomes of treatment, was performed using a visual analogue scale (VAS) [24]. The VAS, used in our study, was modified by us and allowed to objectively evaluate the initial condition and outcomes of treatment of patients with fractures of the midface area. According to the VAS, the following symptoms were evaluated in points: intensity of pain, presence of nasal breathing and nosebleeds on the side of the injury, sensitivity impairements, presence of edema, subcutaneous emphysema, soft tissue hematoma, hemosinus of the maxillary sinus, restriction of mouth opening, "stairs" 
symptom (including malocclusion), visual impairment on the side of the injury, and the magnitude of the displacement of the fragments was also taken into account (according to the data of CBCT).

An objective evaluation of the effectiveness of treatment was performed by comparing the magnitude of displacement of bone fragments before and after treatment. For the convenience of presenting information, a scoring scale was introduced, according to which: 0 points - no displacement, 1 point - displacement from 1 to $3 \mathrm{~mm}$; 2 points $-3.1-6 \mathrm{~mm}$; 3 points $-6.1-9 \mathrm{~mm}$; 4 points $-9.1-12 \mathrm{~mm} ; 5$ points $-12.1-15 \mathrm{~mm}$; 6 points - more than $15 \mathrm{~mm}$.

The results of the study were processed using the STATISTICA - 13.3 software package (license AXA9051924220FAACD-N). Descriptive statistics methods and nonparametric $\chi^{2}$ Pearson and Mann-Whitney criteria were used. In cases of significant variance of indicators, the medians (Me) and quartiles (25\%; $75 \%)$ were calculated.

\section{Results \& Discussion}

The results of the study of the health encounter terms after injury are shown in Table 2. It can be noted that reliable differences in the frequency of encounters within a certain period of time from the moment of injury were detected only between the second and third groups. matic-orbital complex). The patients of this group were divided by the fracture side in the following way: $12(41 \pm 9.1) \%$ of patients had fractures on the right side, $17(59 \pm 9.1) \%$ - on the left side. In the third group $3(11.0 \pm 5.9) \%$ of patients had linear fractures of the midface area zygomatic-orbital complex, $23(82 \pm 7.3) \%-$ small-fragment fractures of zygomatic-orbital complex, $2(7.0 \pm 4.8) \%$ - large-fragment fractures of zygomatic-orbital complex.

The patients of the third group were divided by the fracture side in the following way: $7(25 \pm$ $8.2) \%$ of patients had fractures on the right side, $17(61 \pm 9.2) \%$ of patients - on the left side, 4 $(14 \pm 6.6) \%$ of patients had Le-Fort fractures (on both sides).

The distribution of patients in the study groups by the localization of fractures is shown in Table 3 . According to the data of Table 3 it can be noted that in the reliable majority of patients of all groups, fractures are localized in zygomaticorbital complex ( $40 \%)$, and are accompanied by fractures of the zygomatic arch and bone $(50 \%)$.

Usually with injuries of the midface area there are bone fractures in several places (Table 4).

According to the data of Table 4 it can be noted that in the reliable $\left(\chi^{2}=11.43 ; \mathrm{p}<0.05\right)$ majority of cases (64\%) 3-4 sites of fractures of the midface area, known in the literature as

Distribution of patients by the terms of health encounter, (\%)

Table 2

\begin{tabular}{|l|c|c|c|c|}
\hline \multirow{2}{*}{ Group } & \multicolumn{4}{|c|}{ Term of health encounter, day } \\
\cline { 2 - 5 } & 0 & $1-3$ & $4-7$ & More than 7 \\
\hline $1(n=13)$ & $2(15 \pm 9.9)$ & $6(46 \pm 13.8)$ & $4(31 \pm 12.8)$ & $1(8.0 \pm 7.5)$ \\
\hline $2(n=29)$ & $4(14 \pm 6.4)$ & $10(34 \pm 8.8)$ & $7(24 \pm 7.9)$ & $8(28.0 \pm 8.3)$ \\
\hline $3(n=28)$ & $12(43 \pm 9.4)^{\star}$ & $11(39 \pm 9.2)$ & $2(7.0 \pm 4.8)$ & $3(11.0 \pm 5.9)$ \\
& $x^{2}=5.52$ & & & 12 \\
\hline Total & 18 & 27 & 13 & \\
\hline
\end{tabular}

Note: ${ }^{*}$ - differences in the frequency of encounter of patients within a certain period after injury between the second and third groups are reliable $(\mathrm{p}<0.05)$.

According to the data of Table 2 it can be noted that the reliable $\left(\chi^{2}=11.43 ; \mathrm{p}<0.05\right)$ majority of patients $(64 \%)$ sought treatment within $0-3$ days after injury.

All patients of the first group, $24(83 \pm 7.0) \%$ of patients of the second and $25(89 \pm 5.9) \%$ of patients of the third group had fresh fractures, which constituted the reliable majority in each group.

All patients of the first group had closed smallfragment fractures of the midface area, in $92 \%$ of cases - with localization on the left side. The patients of the second group had closed smallfragment fractures of the midface area (zygo- "tripod fracture" and "tetrapod fracture", were observed simultaneously.

Some patients of the first group, in addition to fractures of the midface area had: fractures of the mandible $-2(15 \pm 9.9) \%$ and fractures of the nasal bones $-6(46 \pm 13.8) \%$. In the second group the following were observed: fractures of the mandible $-1(3.6 \pm 2.8) \%$ and fractures of the nasal bones $-10(34 \pm 8.8) \% .18(62.4 \pm$ $9.0) \%$ of patients in this group had no concomitant fractures. In the third group there were fractures of the mandible in $3(11.0 \pm 5.9) \%$ of cases, fractures of the nasal bones - in $11(46 \pm 13.8) \%$, mandible and nose $-12(43 \pm 9.4) \%$ of cases. 
Table 3

Distribution of patients of the studied groups by the fracture localization

\begin{tabular}{|l|c|c|c|c|c|}
\hline \multirow{2}{*}{ Groups } & \multicolumn{5}{|c}{ Localization of the fracture } \\
\cline { 2 - 6 } & ZOC & ZOC and ZAC & ZA or ZB & ZOC, ZA and ZB & Le-Fort \\
\hline $1(n=13)$ & $4(31 \pm 12.8)$ & 0 & 0 & $9(69 \pm 12.8)$ & 0 \\
\hline $2(n=29)$ & $12(41 \pm 9.1)$ & $1(3.0 \pm 2.8)$ & 0 & $16(55 \pm 9.2)$ & 0 \\
& & $X^{2}=12.42$ & & $10(36 \pm 9.1)$ & $4(14 \pm 6.6)$ \\
\hline $3(n=28)$ & $12(43 \pm 9.4)$ & $1(3.6 \pm 2.8)$ & $1(3.6 \pm 2.8)$ & $35(50 \pm 6.0)$ & $4(5.6 \pm 2.8)^{1,2}$ \\
\hline Total & $28(40 \pm 5.9)$ & $2(3.0 \pm 2.0)^{1,2}$ & $1(1.4 \pm 1.0)^{1,2}$ & & $X^{2}=23.33$ \\
& & $X^{2}=28.68$ & $X^{2}=31.71$ & & $X^{2}=34.16$ \\
\hline
\end{tabular}

Notes: ZOC - zygomatic-orbital complex; ZAK - zygomatic-alveolar complex; ZA - zygomatic arch; $\mathrm{ZB}$ - zygomatic bone; ${ }^{1}$ - differences in the incidence of ZOC fractures and other fractures are reliable $(p<0.05) ;{ }^{2}$ - differences in the incidence of ZOC fractures in combination with ZA and ZB and other fractures are reliable $(\mathrm{p}<0.05)$.

Distribution of patients by the number and localization of fracture sites, (\%)

Table 4

\begin{tabular}{|l|c|c|c|c|c|c|}
\hline \multirow{2}{*}{ Group } & \multirow{2}{*}{ SFZA } & \multirow{2}{*}{ Walls of MS } & \multicolumn{4}{|c}{ Number of fracture sites } \\
\cline { 4 - 7 } & & & 1 & 2 & 3 & 4 \\
\hline $1(\mathrm{n}=13)$ & 0 & 3 & 1 & 0 & 3 & 6 \\
& & $(23 \pm 11.7)$ & $(8.0 \pm 7.5)$ & & $(23 \pm 11.7)$ & $(46 \pm 13.8)$ \\
\hline $2(\mathrm{n}=29)$ & 0 & 4 & 3 & 2 & 7 & 13 \\
& & $(14 \pm 6.4)$ & $(10.0 \pm 5.6)$ & $(7.0 \pm 4.7)$ & $(24 \pm 7.9)$ & $(45 \pm 9.2)$ \\
\hline $3(\mathrm{n}=28)$ & 1 & 3 & 1 & 7 & 4 & 12 \\
& $(3.6 \pm 2.8)$ & $(11.0 \pm 5.9)$ & $(3.6 \pm 2.8)$ & $(25 \pm 8.2)$ & $(14 \pm 6.6)$ & $(43 \pm 9.4)$ \\
\hline Total & 1 & 10 & 5 & 9 & 14 & 31 \\
& $(1.4 \pm 1.0)$ & $(14 \pm 4.1)$ & $(7.0 \pm 3.0)^{1}$ & $(13 \pm 4.0)^{1}$ & $(20 \pm 4.8)^{1}$ & $(44 \pm 5.9)$ \\
\end{tabular}

Notes: SFZA - solitary fracture of zygomatic arch; MS - maxillary sinus; ${ }^{1}-$ differences in the incidence of four and other number of fractures are reliable $(p<0.05)$.

Paresthesia in the infraorbital area was observed in all patients of the first and second groups, in the third group it was in $27(96 \pm 3.7) \%$ of patients. One of the indications for surgical treatment is the presence of hemosinus. Table 5 shows the distribution of patients according to the degree of hemosinus.

According to the data of Table 5 it can be noted that the reliable majority of patients $(90 \%)$ of all groups have hemosinus of varying degrees, which occurred against the background of damage to the walls of the maxillary sinus.
An important indicator that determines the further tactics of treatment of patients is the magnitude of displacement of bone fragments (Table 6).

The analysis of the distribution of patients according to the magnitude of displacement (Table 6) showed that in the first group before the treatment $54 \%$ of patients had a displacement of $9 \mathrm{~mm}$ or more, in the second group there were $37 \%$ of such patients, and after the treatment there were no such patients in the groups. Most patients of these groups ( $85 \%$ and $93 \%$,

Table 5

Distribution of patients with fractures of the midface area by the degree of hemosinus, (\%)

\begin{tabular}{|l|c|c|c|c|}
\hline \multirow{2}{*}{ Group } & \multicolumn{3}{|c|}{ Degree of hemosinus } & \multirow{2}{*}{ Total } \\
\cline { 2 - 5 } & $1 / 3$ of sinus & $2 / 3$ of sinus & Total & $\begin{array}{c}11(85 \pm 9.9)^{*} \\
x^{2}=12.46\end{array}$ \\
\hline $1(n=13)$ & $2(15 \pm 9.9)$ & $6(46 \pm 13.8)$ & $3(23 \pm 11.7)$ & $\begin{array}{c}27(93 \pm 4.7)^{*} \\
x^{2}=43.1\end{array}$ \\
\hline $3(n=29)$ & $4(14 \pm 6.4)$ & $14(48 \pm 9.3)$ & $9(31 \pm 8.6)$ & $\begin{array}{c}25(89 \pm 5.9)^{*} \\
x^{2}=34.57\end{array}$ \\
\hline $3(n=28)$ & $4(14 \pm 6.6)$ & $10(36 \pm 9.1)$ & $11(46 \pm 13.8)$ & \\
\hline
\end{tabular}

Note: $*$ - differences in the incidence of hemosinus in the corresponding group and its absence are reliable $(\mathrm{p}<0.05)$. 
Table 6

Distribution of patients of the studied groups by the magnitude of displacement of bone fragments before and after treatment, (\%)

\begin{tabular}{|c|c|c|c|c|c|c|}
\hline \multirow{2}{*}{$\begin{array}{l}\text { Conditions } \\
\text { of registering }\end{array}$} & \multirow{2}{*}{ Group } & \multicolumn{5}{|c|}{ Displacement, points } \\
\hline & & 1 & 2 & 3 & 4 & 5 \\
\hline \multirow[t]{3}{*}{ Before } & $1(n=13)$ & 0 & $\begin{array}{c}3 \\
(23 \pm 11.7)\end{array}$ & $\begin{array}{c}3 \\
(23 \pm 11.7)\end{array}$ & $\begin{array}{c}6 \\
(46 \pm 13.8)\end{array}$ & $\begin{array}{c}1 \\
(8.0 \pm 7.5)\end{array}$ \\
\hline & $2(n=29)$ & 0 & $\begin{array}{c}4(14 \pm 6.4)^{*} \\
x^{2}=25.02\end{array}$ & $14(48 \pm 9.3)$ & $10(34 \pm 8.8)$ & $1(3.6 \pm 2.8)$ \\
\hline & $3(n=28)$ & $2(7.0 \pm 4.8)$ & $15(54 \pm 9.4)$ & $6(21 \pm 7.7)$ & $4(14 \pm 6.6)$ & $4(14 \pm 6.6)$ \\
\hline \multirow[t]{3}{*}{ After } & $1(n=13)$ & $\begin{array}{c}2 \\
(15 \pm 9.9)\end{array}$ & $\begin{array}{c}7 \\
(54 \pm 13.8)\end{array}$ & $\begin{array}{c}4 \\
(31 \pm 12.8)\end{array}$ & $\begin{array}{c}0^{*} \\
X^{2}=7.8\end{array}$ & 0 \\
\hline & $2(n=29)$ & $2(7.0 \pm 4.7)$ & $23(79 \pm 7.6)$ & $4(14 \pm 6.4)$ & $\begin{array}{c}0^{*} \\
X^{2}=12.08 \\
\end{array}$ & 0 \\
\hline & $3(n=28)$ & $2(7.0 \pm 4.8)$ & $15(54 \pm 9.4)$ & $6(21 \pm 7.7)$ & $4(14 \pm 6.6)$ & $4(14 \pm 6.6)$ \\
\hline
\end{tabular}

Notes: * - differences in the frequency of the corresponding points in the group before and after treatment are reliable $(\mathrm{p}<0.05)$.

respectively) had the final displacements in the range of $3.1-6 \mathrm{~mm}$. In the third group of patients treated conservatively, in most cases ( $93 \%$ ) the displacements were greater than $3.1 \mathrm{~mm}$, which remained after conservative treatment.

Thus, in all studied groups, the displacement of bone fragments, which had not only cosmetic but also functional consequences, remained in the majority of patients.

In order to evaluate the cosmetic effect before and at different periods of treatment, the points according to the VAS were calculated.

For clarity of the presentation, scale diagrams were constructed (Figure). Friedman criterion, which is used to analyze repeated measurements associated with the same object, was used to evaluate the results obtained by the VAS.

In all studied groups, a certain cosmetic effect was achieved over time, as evidenced by a reliable $\left(\chi^{2}=160.9 ; p=0.00000\right)$ decrease of the indicator. In the first and second groups according to Figure there is an increase in the indicator after surgery, due to postoperative edema.

Further, the indicator by the VAS decreases. In the third group, where the patients were not operated, the indicator was decreasing throughout the observation period. No reliable differences were found between the groups by the VAS before surgery and 30 days after it.

In modern clinical practice, visualization and clinical methods are used to evaluate the results of treatment of facial area fractures [25, 26].

There are data in the literature on the use of the VAS points as clinical indicators. The authors use the VAS to evaluate the condition of patients by fractures of the nasal bones [27], fractures of the mandible [28], but in the available literature we have not found information on the use of the VAS to evaluate the quality of treatment of fractures of the midface area.

Therefore, in this study we used the VAS developed by us, which made it possible to objectively evaluate the results of treatment of patients with fractures of the midface area. To evaluate the anatomical features of fractures and the quality of their correction in different ways, CBCT was used.

We have found that both methods of repositioning the fragments allow, to a certain extent, to obtain a positive result in the treatment of fractures of the midface area, but in most cases the displacement of bone fragments remains. If
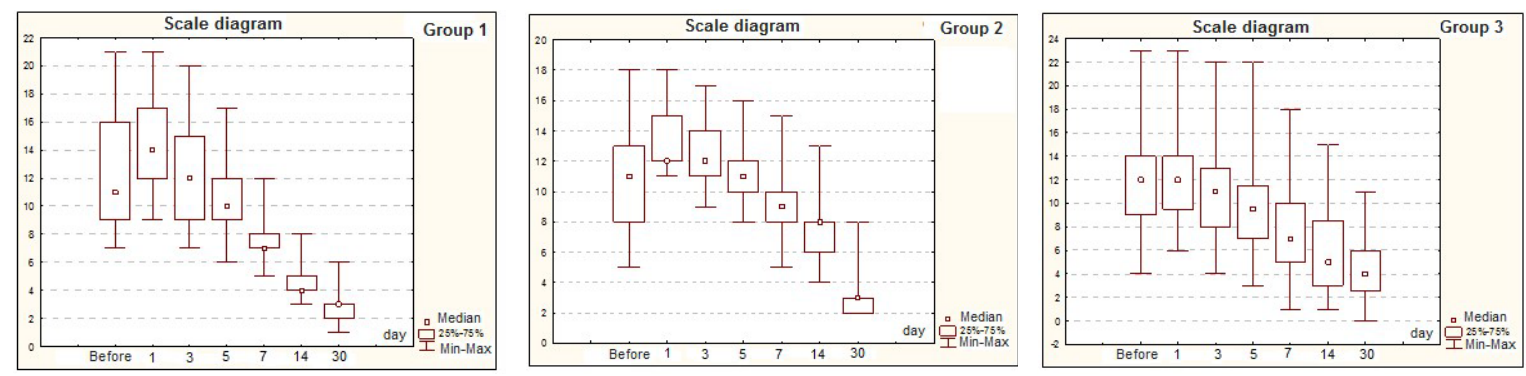

Scale diagrams of the indicator by the VAS in the studied groups 
patients are treated conservatively, the displacement of bone fragments remains forever. This indicates the imperfection of the analyzed methods.

Thus, a comparative analysis of the results of treatment of patients with fractures of the midface area showed that in most of them there were final cosmetic and functional deficiencies, which remained in the long-term observation. Displacement of bone fragments can remain when using any of the analyzed treatment methods.

\section{Conclusions}

1. Evaluation of the period of seeking medical care showed that the reliable $\left(\chi^{2}=11.43 ; p<0.05\right)$ majority of patients $(64 \%)$ sought treatment within $0-3$ days after injury.

2. 83-89\% of patients, who underwent repositioning of fragments, had fresh small-fragment fractures. The reliable $\left(\chi^{2}=11.43 ; p<0.05\right)$ majority of them simultaneously had 3-4 sites of bone fractures of the midface area, hemosinus of varying degrees and paresthesia in the infraorbital area.

3. In the majority of patients, who underwent repositioning of bone fragments with and without tamponade ( $85 \%$ and $93 \%$, respectively), the final displacements were in the range of 3.1-6 mm. In patients treated conservatively, in most cases (93\%) the displacements were greater than $3.1 \mathrm{~mm}$, which remained after treatment. In the majority of patients treated with the studied methods, in the long term, the displacements of bone fragments remained, which had functional consequences.

4. In all studied groups, a certain cosmetic effect was achieved over time, as evidenced by a reliable $\left(\chi^{2}=160.9 ; p=0.00000\right)$ decrease in the indicator by the VAS.

The prospect for further research is a comparative evaluation of the results of treatment of fractures of the midface area using the methods of bone osteosynthesis methods to fixate the fragments using standard titanium mini-plates and individual 3-D simulated titanium mini-grids.

\section{Declarations:}

\section{Statement of Ethics}

The authors have no ethical conflicts to disclosure.

\section{Consent for publication}

All authors give their consent to publication.

\section{Disclosure Statement}

The authors have no potential conflicts of interest to disclosure.

\section{Funding Sources}

This study was not supported by any grants from public, commercial or other sectors

\section{Data Transparency}

The data can be requested from the authors.

\section{References}

1. Gassner, R., Tuli, T., H?chl, O., Rudisch, A., \& Ulmer, H. (2003). Cranio-maxillofacial trauma: a 10 year review of 9543 cases with 21067 injuries. Journal of cranio-maxillofacial surgery, 31(1), 51-61. doi: 10.1016/s1010-5182(02)00168-3

2. Mast, G., Ehrenfeld, M., Cornelius, C. P., Litschel, R., \& Tasman, A. J. (2015). Maxillofacial Fractures: Midface and Internal Orbit-Part I: Classification and Assessment. Facial Plastic Surgery, 31(04), 351-356. doi: 10.1055/s-0035-1563692

3. Li, H., Lu, R. J., Wu, P., Yuan, Y., Yang, S., Zhang, F. F., .. Tan, Y. (2021). Numerical simulation and analysis of midfacial impacts and traumatic brain injuries. Annals of translational medicine, 9(6), 459. doi: $10.21037 / \mathrm{atm}-21-134$

4. Dagasan, V. C., Burdurlu, M. C., \& Baysal, E. (2020). Diagnosis and management of midfacial fractures. In C. Evereklioglu (Ed.), Academic Studies in Health Sciences - II (155-166). Ankara, Turkey: Gece Publishing.

5. Vrinceanu, D., Banica, B., \& Dumitru, M. (2021). Diagnosis and Treatment of Midface Trauma in the Context of Polytrauma: Characteristics during COVID-19 Pandemic Conditions. In G. Tsoulfas (Ed.), Trauma and Emergency Surgery - The Role of Damage Control Surgery. Rijeka, Croatia: IntechOpen. doi:10.5772/intechopen.92862

6. Nazarevych, M. R., Ohonovskyi, R. Z., Melnychuk, Yu. M., Pohranychna, Kh. R., \& Ilnytskyi, Ya. M. (2020). Rezul'taty doslidzhennja stresovyh reakcij u hvoryh iz pojednanoju travmoju seredn'oi' zony oblychchja pislja zastosuvannja kompleksnoi' pisljaoperacijnoi' reabilitacii' [Results of the stress reactions study in patients with combined injuries of the midface area after using of complex postoperative rehabilitation]. Klinichna stomatologija, (2), 43-51. doi: 10.11603/2311-9624.2020.2.11399

7. Brehlichuk, P. P. (2018). Analitychna ocinka chastoty vynyknennja travmatychnyh urazhen' shhelepno-lycevoi' diljanky v rezul'tati dorozhn'o-transportnyh prygod [Analytical estimation of the maxillofacial trauma frequency after road traffic accidents]. Sudovo-medychna ekspertyza, (2), 106-112. 
8. Shuminsky, E., \& Kopchak, A. (2021). Shestyrichnyj analiz travmatychnyh poshkodzhen' cherepnoshhelepno-lycevoi' diljanky: zv'jazok shelepno-lycevoi' ta cherepno-mozkovoi' travm [Six-year analysis of traumatic injuries of the craniomaxillofacial area: relation between maxillofacial and traumatic brain injuries]. Suchasna stomatologija, (1), 56-60. doi: 10.33295/1992-576x-2021-1-56

9. Kaura, S., Kaur, P., Bahl, R., Bansal, S., \& Sangha, P. (2018). Retrospective study of facial fractures. Annals of maxillofacial surgery, 8(1), 78-82. doi: 10.4103/ams.ams_73_17

10. Abhinav, R. P., Selvarasu, K., Maheswari, G. U., \& Taltia, A. A. (2019). The patterns and etiology of maxillofacial trauma in South India. Annals of maxillofacial surgery, 9(1), 114-117. doi: 10.4103/ ams.ams_233_18

11. Sheth, S., Sharma, A. S., Mehta, S. K., Kachwala, H., Parker, N., \& Pandya, D. (2017). Knowledge, attitude, and practices of dental students toward human immunodeficiency virus/acquired immunodeficiency syndrome of AMC Dental College and Hospital, Ahmedabad, Gujarat: A cross-sectional study. Journal of International Oral Health, 9(6), 284-288.

12. Kuhnel, T. S., \& Reichert, T. E. (2015). Trauma of the midface. GMS current topics in otorhinolaryngology, head and neck surgery, 14, Doc06. doi: 10.3205/cto000121

13. Kim, R., Shokri, T., Wang, W., \& Ducic, Y. (2021). Facial Protection to Prevent Facial Trauma and Allow for Optimal Protection after Facial Fracture Repair. Facial Plastic Surgery. doi: 10.1055/s0041-1723006

14. Marimuthu, M., Andiappan, M., Wahab, A., Muthusekhar, M. R., Balakrishnan, A., \& Shanmugam, S. (2018). Canonical Wnt pathway gene expression and their clinical correlation in oral squamous cell carcinoma. Indian Journal of Dental Research, 29(3), 291-297. doi: 10.4103/ijdr.IJDR_375_17

15. Shamanaeva, L., Diachkova, E., Petruk, P., Polyakov, K., Cherkesov, I., \& Ivanov, S. (2020). Titanium Nickelide in Midface Fractures Treatment. Journal of functional biomaterials, 11(3), 52. doi: $10.3390 / \mathrm{jfb} 11030052$

16. Siauw, C., Syamsudin, E., \& Ismiarto, Y. D. (2019). Ballooning technique for orbital floor fracture reduction in neglected midfacial fracture: a case report. Journal of Case Reports in Dental Medicine, 1(2), 43-48. doi: 10.20956/jcrdm.v1i2.88

17. Reiter, M. J., Schwope, R. B., \& Theler, J. M. (2017). Postoperative CT of the Midfacial Skeleton After Trauma: Review of Normal Appearances and Common Complications. American Journal of Roentgenology, 209(4), W238-W248. doi: 10.2214/AJR.17.17875

18. Jo, E. J., Kim, J. H., \& Yang, H. J. (2015). Inferior Blow-Out Fracture Reduction Using Two Urinary Balloon Catheters. Archives of craniofacial surgery, 16(3), 114-118. doi: 10.7181/acfs.2015.16.3.114

19. Hong, S. O., Lee, D. W., Lee, J. W., \& Jung, J. H. (2013). Minimal invasive and cost-effective method in reduction of maxillofacial fracture by using a Foley catheter ballooning technique. Journal of Craniofacial Surgery, 24(6), e585-e588. doi: 10.1097/SCS.0b013e31829ad3c3

20. Dong, Z., Li, Q., Bai, S., \& Zhang, L. (2015). Application of 3-dimensional printing technology to Kirschner wire fixation of adolescent condyle fracture. Journal of Oral and Maxillofacial Surgery, 73(10), 1970-6. doi: 10.1016/j.joms.2015.04.005

21. Nikolaenko, V. P., Astakhov, Y. S., Soloviev, M. M., Khatskevich, G., \& Trofimov, I. G. (2015). Zygomaticoorbital Fractures. In V. P. Nikolaenko \& Y. S. Astakhov (Eds.), Orbital Fractures: A Physician's Manual (271-301). Berlin: Springer. doi: 10.1007/978-3-662-46208-9_6

22. Gareb, B., Roossien, C. C., van Bakelen, N. B., Verkerke, G. J., Vissink, A., Bos, R. R., \& van Minnen, B. (2020). Comparison of the mechanical properties of biodegradable and titanium osteosynthesis systems used in oral and maxillofacial surgery. Scientific reports, 10(1), 1-18. doi: 10.1038/s41598-02075299-9

23.Vujcich, N., \& Gebauer, D. (2018). Current and evolving trends in the management of facial fractures. Australian dental journal, 63 Suppl 1, S35-S47. doi: 10.1111/adj.12589

24. Voloshan, O., Grigorov, S., \& Demyanyk, D. (2020). Development and analysis of diagnostic criteria for creation of an automated computer software for predicting the course and individualizing the treatment of patients with odontogenic maxillary sinusitis. Wiadomosci lekarskie, 73(4), 767-772. doi: 10.36740/WLek202004127

25. de Carvalho, M. F., Vieira, J. N. M., Figueiredo, R., Reher, P., Chrcanovic, B. R., \& Chaves, M. (2021). Validity of computed tomography in diagnosing midfacial fractures. International Journal of Oral and Maxillofacial Surgery, 50(4), 471-476. doi: 10.1016/j.ijom.2020.09.002 
26. Singh, A. K., Dhungel, S., \& Yadav, M. (2020). Intraoperative ultrasound imaging in the closed reduction of zygomatic arch fracture: Getting it right the first time. Oral and Maxillofacial Surgery Cases, 6(4), 100202. doi: 10.1016/j.omsc.2020.100202

27. Kim, J., Jung, H. J., \& Shim, W. S. (2018). Corrective septorhinoplasty in acute nasal bone fractures. Clinical and experimental otorhinolaryngology, 11(1), 46-51. doi: 10.21053/ceo.2017.00346

28. Jalil, L. H. (2019). Evaluation of Post-Operative Complications of Subcondylar Fractures Treated with Conservative Method. Journal of University of Babylon for Pure and Applied Sciences, 27(3), 90-102.

Received: 02-Feb-2020

Accepted: 03-Jun-2020 